\title{
The Power-Sharing Event Dataset (PSED): A new dataset on the promises and practices of power-sharing in post-conflict countries'
}

\author{
Martin Ottmann \\ GIGA German Institute of Global and Area Studies, Germany \\ Johannes Vüllers \\ GIGA German Institute of Global and Area Studies, Germany
}

\begin{abstract}
Past research on the relationship between power-sharing arrangements and the recurrence of civil conflict has primarily analyzed the promises of power-sharing stipulated in peace agreements. What happens afterwards, however, has not yet been sufficiently explored. This represents a major research gap, as the actual practices of power-sharing in post-conflict countries are likely to be influential in the possibility of civil conflict recurring. To address this shortcoming, we present a new global dataset on the promises and practices of power-sharing between the government of a state and former rebels in post-conflict countries. The collected data captures if, when and how power-sharing institutions have been promised and/or put into place, and whether they have subsequently been modified or abolished. The dataset encompasses every peace agreement signed after the cessation of a civil conflict in the years between 1989 and 2006, and covers a five-year period after the signature of each of these agreements (unless violence recurred earlier). The unit of analysis is the government-rebel dyad during the post-conflict period and data is recorded in an event data format. A first analysis of the Power-Sharing Event Dataset (PSED) reveals that the effects of the promises of power-sharing on civil conflict recurrence follow a different logic than the effects of their practices. This finding emphasizes the necessity for in-depth analyses of postconflict situations for which the PSED provides the necessary data.
\end{abstract}

\section{Keywords}

Civil conflict, dataset, event data, government-rebel dyads, power-sharing, post-conflict countries

Corresponding author:

Martin Ottmann, GIGA German Institute of Global and Area Studies, Neuer Jungfernstieg 2I, 20354 Hamburg, Germany. Email: martin.ottmann@giga-hamburg.de 


\section{Introduction}

Do power-sharing arrangements lead to durable peace? In the last decade several studies have empirically analyzed the effects of power-sharing provisions negotiated in settlements on peace. The data employed in these studies, however, often only captures the promises of power-sharing agreements and not the actual practices of power-sharing in post-conflict countries. Our knowledge about the actual occurrence of power-sharing and, following from this, our insights about the impact of power-sharing arrangements on the recurrence of civil conflicts are, therefore, still limited. ${ }^{2}$ To address this research gap, we present the innovative Power-Sharing Event Dataset (PSED) that systematically collects information on the promises and practices of power-sharing between governments and rebels in an event data format for a five-year period after the conclusion of a peace agreement (unless violence recurred earlier). The main features of this dataset are the specific focus on government-rebel dyads during post-conflict periods, an exact temporal mapping of implemented or abolished power-sharing events and detailed descriptions for each power-sharing arrangement put into practice.

In the next section we discuss the theoretical impetus behind the compilation of this dataset. The third section describes the key concepts, dataset structure and data collection procedures employed in the PSED. The fourth section presents descriptive statistics as well as regional and temporal patterns of power-sharing in 41 post-conflict countries. In the penultimate section we demonstrate the utility of the PSED with a first statistical analysis of the effect of promises of power-sharing and their implementation on civil conflict recurrence. The final section concludes the article.

\section{Why a new dataset?}

There is no unanimous scholarly definition of what power-sharing actually is (Binningsbø, 2013). In some studies power-sharing is narrowly understood as the inclusion of the political opposition in joint national governments (Walter, 2002). Others, in contrast, follow Lijphart's (1969) concept of consociational democracy and focus on a wide variety of political, economic and territorial arrangements of power-sharing in divided societies (Norris, 2008). Some focus exclusively on short-term measures of conflict resolution in post-conflict countries (Glassmyer and Sambanis, 2008). Others regard power-sharing as a long-term approach toward reconciliation of diverse interests in societies (Roeder and Rothchild, 2005). While all of these different approaches towards the phenomenon of power-sharing undoubtedly have their merits, scholarly research needs to focus on one understanding of this phenomenon at a time in order to incrementally move forward our body of knowledge on power-sharing writ large. In the remainder of this article, we therefore focus on powersharing understood as any arrangement between the government of a state and rebel groups that gives guarantees to each party regarding the use of state power. This definition of power-sharing is informed by our interest in exploring the use of power-sharing as a tool of conflict resolution in post-conflict countries.

However, even when resting on the basis of such a common understanding, scholars have not yet been able to reach a consensus on the question whether power-sharing ultimately fulfils its promise (Binningsbø, 2013). Some scholars, for example, argue that power-sharing has negative effects on peace (e.g. Jarstad and Sisk, 2008; Mehler, 2009; Rothchild and Roeder, 2005; Tull and Mehler, 2005). This reasoning rests on the fact that power-sharing 
often primarily focuses on the interests and needs of those persons and groups that started the civil conflict in the first place. Power-sharing then provides incentives for these elites to threaten a return to violence in order to extort even more concessions (Rothchild and Roeder, 2005). Alternatively, concessions to rebel elites might induce other elites and their armed groups excluded from a peace agreement to begin or increase their opposition to a government in the hope of receiving comparable concessions (Mehler, 2009; Tull and Mehler, 2005). Moreover, power-sharing often sets up an institutional framework that consolidates group identities and perpetuates antagonistic relationships and zero-sum situations between these groups. In the long term, post-conflict power-sharing might therefore sow the seed for future civil conflicts.

In contrast, a second body of research suggests that power-sharing has indeed a pacifying effect in post-conflict countries. Even within this strand of research, however, there is still surprisingly little systematic empirical evidence on the prospects of post-conflict powersharing. Distinguishing between political, territorial, military and economic forms of powersharing, for example, Hartzell and Hoddie (2007) expect all four dimensions to be important for securing peace. Specifically, they find that, the higher the 'settlement institutionalization' is - that is, the more types of power-sharing are included in a peace agreement - the higher is the likelihood that peace will prevail. This 'the more, the better' hypothesis, however, has only received partial support in other studies. Walter (2002) for one suspects that groups are likely to be particularly concerned with executive power because a politically powerful and popular leader will have relatively few constraints on behaviour. Jarstad and Nilsson (2008), however, disagree based on the hypothesis that military and territorial power-sharing involves higher logistical, economic and immaterial costs than do political pacts, which makes them more suitable to function as a 'costly signal'.

Analyzing the effects of each of these power-sharing dimensions on its own, some studies find evidence for a positive relationship between political power-sharing and durable peace. Binningsbø (2006) reports that the existence of a 'grand coalition' has a significant positive impact on post-conflict peace duration. Mattes and Savun (2009) argue that, in particular, political power-sharing (defined as a representative electoral system, distribution of cabinet portfolios and integration of rebels into civil services) reduces combatants' fears that the other side will take up arms again. Similarly, Cammett and Malesky (2012) find that closedlist proportional representation systems have a significant positive impact on peace duration. Other studies, in contrast, conclude that political pacts do not exercise a positive influence on post-conflict peace duration (DeRouen et al., 2010; Jarstad and Nilsson, 2008). In an again somewhat different vain, Mukherjee (2006) finds that promises of political powersharing after civil conflicts ending in military stalemates do not make peace more likely to last, whereas the reverse is true for power-sharing after military victories.

Regarding military power-sharing, Hoddie and Hartzell (2005), DeRouen et al. (2010) and Jarstad and Nilsson (2008) report a positive relationship between military power-sharing and post-conflict peace duration. Both Walter (2002) and Glassmyer and Sambanis (2008), however, find no evidence for such association. In particular, the latter's in-depth analysis of rebel-military integration agreements concludes that the military integration of rebels has no significant effect on peace duration.

According to the few studies with such a focus, economic post-conflict power-sharing also appears not to have an impact on peace duration. Hartzell and Hoddie (2007) as well as Mattes and Savun (2009) find no statistically significant positive effect of economic powersharing on post-conflict peace duration. Employing a broad definition of power-sharing, 
Binningsbø and Rustad (2012) collected new data on resource wealth redistribution, allocation of decision-making power over natural resources and land reforms in order to explore the effect of economic power-sharing on post-conflict peace. However, they also do not find a statistically significant positive impact of any of these three forms of economic powersharing sharing on post-conflict peace duration.

Finally, the findings concerning the effects of territorial power-sharing are also contradictory. Hoddie and Hartzell (2005), Walter (2002), Jarstad and Nilsson (2008) and DeRouen et al. (2009) provide evidence for a positive statistical relationship between territorial powersharing and durable peace, while Binningsbø (2006) and Pearson et al. (2006) find no significant association. Lake and Rothchild (2005) come to the conclusion that political instability and conflict are an almost certain consequence of territorial power-sharing.

Taken together, the actual effect of post-conflict power-sharing on the recurrence of internal armed conflict remains unclear. It might have a destructive effect on post-conflict peace, it might have a pacifying effect or it might not have any effect at all. Especially with regard to statistical research, we argue that one reason preventing the emergence of a consensus on this question is a widely varying understanding of power-sharing and, following from that, an inconsistent application of bargaining theory as the dominant theoretical framework to empirical research designs.

Bringing an end to protracted civil conflict is a difficult business. Even if conflict parties have agreed to come to the bargaining table, it is a formidable challenge to convince both sides to permanently lay down their arms and continue their political competition with peaceful means. At the core of this challenge lies the 'security dilemma' (Snyder and Jervis, 1999). Even though the combatants may in principle become more secure by disarming, each party fears the defection of the others. Walter's (2002) 'credible commitment theory' therefore posits that combatants will walk away from the negotiating table as long they believe that a settlement could leave them permanently excluded from political power and expose them to continued abuse. Power-sharing, it is argued, helps to overcome this security dilemma (Hartzell and Hoddie, 2007; Walter, 2002). Power-sharing provisions in a peace agreement can prevent a recurrence to armed conflict - as they allow both conflict parties to credibly commit to the negotiated settlement and demonstrate their continuing loyalty to the peace process. That is, there is a direct link between the involved conflict actors, powersharing and civil conflict recurrence. Peace agreements are negotiated and agreed upon between representatives of the government and rebel leaders, which ultimately means that these actors commit only themselves to the settlement.

However, the data used to measure power-sharing as a means of credible commitments of governments and rebels in post-conflict countries is frequently built upon very different understandings of power-sharing. Some scholars include measures capturing power-sharing provisions simultaneously aimed at rebel movements and ethnic groups alike. Hoddie and Hartzell (2005) and Mattes and Savun (2009), for example, include in their 'political powersharing' variables a combination of actor-level factors such as proportional representation by rebels in the national government and group-level provisions such as electoral proportional representation for societal groups. Others, like Cammett and Malesky (2012), focus almost exclusively on group-level provisions in order to analyze the commitment of conflict actors to the peace deal. These operationalizations become problematic if more than one rebel group claims to represent a societal group, if only the interests of a rebel group are satisfied while the grievances of the societal group are not considered, or when only the interests of the societal group is considered while the interests of the rebels are disregarded. 
Moreover, many large- $N$ studies have confined themselves to analyzing the effects of power-sharing promises, that is, the mere inclusion of power-sharing provisions in a peace agreement (e.g. DeRouen et al., 2010; Mukherjee, 2006; Pearson et al., 2006). If the government and rebels agree on an integrated national army in a peace agreement, for example, this mere promise of military power-sharing is often implicitly equated with the eventual implementation of it. It might well be the case, however, that the government and rebels never follow up these words with actual deeds - large- $N$ research on power-sharing in postconflict countries needs to account for this possibility. After all, the failure to implement credible commitments robs them of their credibility.

So far, only a few studies have explicitly investigated how the implementation of powersharing agreements affects durable peace (Hartzell and Hoddie, 2007; Hoddie and Hartzell, 2003; Jarstad and Nilsson, 2008). While Hoddie and Hartzell's studies can only utilize a small sample on implemented military power-sharing arrangements, Jarstad and Nilsson (2008) have constructed a larger dataset addressing this lacuna in past research. Their Implementation of Pacts (IMPACT) dataset, however, still lacks an explicit focus on conflict actors and disregards important temporal information. For example, while they do note whether or not power-sharing in either the political, military and/or territorial dimensions has been implemented at the end of the five-year periods, they do not capture which rebel group exactly benefitted from it and when exactly these power-sharing institutions were introduced (or later abolished). ${ }^{3}$

In light of this discussion, we conclude that statistical research needs to be more aware of the theoretical and empirical consequences of different conceptualizations of power-sharing. One way to address this in future research is the use of clearly conceptualized and disaggregated data on particular types of post-conflict power-sharing. Such data has the potential to provide us with new insights into post-conflict power-sharing complementing past research in this field. To this end, we present the PSED. This new data collection is tailored to explicitly test the assumptions of bargaining and credible commitment theory. Among its key features are an exclusive focus on the conflict actors, detailed and disaggregated information on power-sharing arrangements and a detailed temporal mapping of the promises and practices of power-sharing.

\section{Measuring power-sharing in post-conflict countries}

The PSED universe of cases encompasses all peace agreements ending a civil conflict between the government of a state and one or more rebel groups signed between 1989 and 2006. For each of these peace agreements, we collected data on power-sharing between government and rebels taking place at any point within a five-year post-conflict period. If armed combat between government and rebels recurred within this five-year post-conflict period, we used the date of civil conflict recurrence as the end point for our data collection. ${ }^{4}$ This operationalization of a post-conflict period is motivated by our general research interest to understand the effect of power-sharing between government and rebels on the probability that a civil conflict between these actors recurs. The focus on the first five years of a post-conflict period has been established as common threshold in past research on post-conflict power-sharing (e.g. Hartzell and Hoddie, 2007; Jarstad and Nilsson, 2008; Walter, 1999).

To define and operationalize the concepts of 'civil conflict', 'peace agreement' and 'civil conflict recurrence', we relied on the definitions developed by the Uppsala Conflict Data 
Program (UCDP) for its armed conflicts datasets (Gleditsch et al., 2002; Harbom et al., 2008). Statistical analyses using the PSED are therefore compatible with one of the major data collections in the field of conflict research. This ensures the comparability of empirical findings based on the PSED with the large and continuously growing body of research using UCDP data. It also allows researchers to integrate the PSED in novel ways with other data collections using the UCDP definitions and concepts. ${ }^{5}$ The downside of this compatibility, however, is that criticisms regarding UCDP's definition of what constitutes an 'internal armed conflict' and its deliberate focus on a low-battle-deaths inclusion criterion for its data collections also apply to the PSED (e.g. Gates and Strand, 2004). ${ }^{6}$

In the remainder of this section, we will define and operationalize the concept of postconflict power-sharing, present the PSED data structure and data sources and discuss possible limitations of our data collection.

\section{Definition of power-sharing}

We define power-sharing as any arrangement between the government of a state and a rebel group that promises to establish institutions that mandate joint control of power at the national level of government. Reflecting Hartzell and Hoddie's (2007: 28-38) four-part typology of power-sharing arrangements, we also differentiate between power-sharing in the political, military, economic and territorial dimensions of power.

With this definition, we clearly locate power-sharing at the level of government and rebel groups actors. In turn, this means that we exclude power-sharing arrangements that aim at rebel groups that have not signed the peace agreement or that aim exclusively at societal groups such as, for example, ethnic or religious groups. ${ }^{7}$ While this definition admittedly reflects a restrictive understanding of power-sharing, we argue that an exclusive focus on power-sharing between the parties to a peace agreement is better suited to testing existing actor-centric theories of post-conflict power-sharing.

Power-sharing defined in such a way plays a twofold role in post-conflict situations. First, it is important what promises of power-sharing the government of a state has given to rebel groups at the bargaining table at the very end of a civil conflict. The role of these promises of power-sharing is to assure the conflict parties that they intend to keep the peace. Second, the actual practices of power-sharing between government and rebels taking place in the aftermath of the conflict are important. The practices of power-sharing in the postconflict context refer to the actual implementation (or non-implementation) of promises of power-sharing. This concept of the practices of power-sharing can also be decoupled from the promises of power-sharing. Quite frequently, governments and rebels do not agree on particular promises of power-sharing but nevertheless practice power-sharing in the postconflict period. ${ }^{8}$

\section{Data structure}

The unit of analysis in our data collection is the government-rebel dyad during the postconflict period, that is, the pair of warring parties in a civil conflict that have signed a peace agreement. In multiparty conflicts, peace agreements often contain more than one government-rebel dyad. The use of the government-rebel dyad as a unit of analysis then disaggregates these peace agreements and treats the relationship between the government side and each of the rebel group signatories separately. ${ }^{9}$ 
Within each government-rebel dyad, the PSED contains data on the promises and practices of power-sharing. Regarding the former, we have coded for each dyad what kind of power-sharing has been promised by the government of a state to the rebel group. As the content of a signed peace agreement will not change during the post-conflict period, our information on the promises of power-sharing is time-invariant. ${ }^{10}$

Turning to the practices of power-sharing, the PSED includes information on the occurrence of power-sharing within a government-rebel dyad at any given time during the fiveyear post-conflict period, unless violence recurs earlier. This information is coded in an event data format. In line with our definition of power-sharing presented above, we understand a power-sharing event as the introduction or abolishment of a power-sharing arrangement between the government of a state and a rebel group at any point during the five-year postconflict period studied. We also amended each power-sharing event with detailed information on time, type, actors involved, event description and raw data. By doing this, we provide the users of our dataset with additional information that can be used to further disaggregate our event types or to construct new event types. Moreover, the additional information will also encourage the use of our dataset for qualitative comparisons of a small number of cases.

Our data on the practices of power-sharing is not restricted only to those instances of powersharing that implement promises of power-sharing made at the bargaining table at the end of the conflict. Rather, we include every instance of power-sharing between government and rebels taking place in the aftermath of a civil conflict. This separation of the general concept of postconflict power-sharing from the question of promises of power-sharing and their subsequent implementation allows a more flexible use of the PSED. While our data on post-conflict powersharing can be easily restricted using information on the promises of power-sharing, our definition of power-sharing as power-sharing practices allows the PSED to be used to answer a wider set of questions regarding the occurrence and effect of post-conflict power-sharing.

Table 1 illustrates the resulting data structure of the PSED. In this simplified data structure, data on three government-rebel dyads is displayed. The first dyad is the only government-rebel pair that has signed a peace agreement. The next two dyads are both party to the same peace agreement. In the PSED, we collect data on the promises and practices of power-sharing for each of these two dyads separately. By examining the columns containing the power-sharing variables in Table 1, one can see how the setup of our data collection allows differentiation between the promises and practices of power-sharing between different government-rebel dyads.

In our simple example, the rebels of 'Dyad A' were promised economic and territorial power-sharing arrangements. The column displaying the actual practices of power-sharing, however, shows that only economic power-sharing has been implemented. The rebels have never received any territorial power but instead are part of a political power-sharing arrangement. Such deviations from the original peace deal are actually quite common in postconflict situations. The stylized example of Table 1 partly reflects what happened between the government of Djibouti and the Front for the Restoration of Unity and Democracy. While they were promised territorial decentralization in the 1994 peace deal, this promise was never put into practice. Instead, one could observe that leaders of the former rebels were given seats in the national government. If one only examined whether the provisions of the 1994 peace deal were implemented, only the absence of the territorial power-sharing would be noted while the information on political power-sharing would be lost.

The two remaining government-rebel dyads in Table 1, 'Dyad B' and 'Dyad C', are both part of the same peace deal, a 'Comprehensive Peace Agreement'. An example of such a 
Table I. Illustration of the PSED data structure

\begin{tabular}{|c|c|c|c|c|c|}
\hline \multirow[b]{2}{*}{ ID } & \multirow[b]{2}{*}{ Peace agreement } & \multirow[b]{2}{*}{$\begin{array}{l}\text { Government- } \\
\text { rebel dyad }\end{array}$} & \multicolumn{3}{|l|}{ Power sharing variables } \\
\hline & & & Promise & Practice & Event date \\
\hline 1 & $\begin{array}{l}\text { Memorandum of } \\
\text { Understanding }\end{array}$ & Dyad A & Economic and territorial & Economic & 01 Jan 1994 \\
\hline 1 & $\begin{array}{l}\text { Memorandum of } \\
\text { Understanding }\end{array}$ & Dyad A & Economic and territorial & Economic & 15 Mar 1994 \\
\hline 1 & $\begin{array}{l}\text { Memorandum of } \\
\text { Understanding }\end{array}$ & Dyad A & Economic and territorial & Political & 30 Jun 1995 \\
\hline 2 & $\begin{array}{l}\text { Comprehensive Peace } \\
\text { Agreement }\end{array}$ & Dyad B & Political and military & Military & 15 Apr 2000 \\
\hline 2 & $\begin{array}{l}\text { Comprehensive Peace } \\
\text { Agreement }\end{array}$ & Dyad B & Political and military & Political & I5 May 2000 \\
\hline 2 & $\begin{array}{l}\text { Comprehensive Peace } \\
\text { Agreement }\end{array}$ & Dyad B & Political and military & Economic & 30 Mar 200I \\
\hline 3 & $\begin{array}{l}\text { Comprehensive Peace } \\
\text { Agreement }\end{array}$ & Dyad C & Political & Political & 15 Apr 2002 \\
\hline 3 & $\begin{array}{l}\text { Comprehensive Peace } \\
\text { Agreement }\end{array}$ & Dyad C & Political & Political & 15 May 2003 \\
\hline 3 & $\begin{array}{l}\text { Comprehensive Peace } \\
\text { Agreement }\end{array}$ & Dyad C & Political & Political & 30 Aug 2004 \\
\hline
\end{tabular}

multiparty peace deal is the Final Act of the Inter-Congolese Political Negotiations signed in the Democratic Republic of Congo in 2003. It was signed between the government and the rebel groups Congolese Rally for Democracy (RCD), its splinter group RCD-ML and the Movement for the Liberation of Congo (MLC). Our example in Table 1 shows that the rebel groups of 'Dyad B' and 'Dyad C' received very different promises of power-sharing. The former received political and military concessions whereas the latter only received political promises. The disparities between both rebel groups continued in the post-conflict period. As promised, 'Dyad B' practiced political and military power-sharing. Moving beyond the original agreement, it also established an economic power-sharing arrangement. The information in the event data column also shows that all these agreements were implemented relatively quickly. The rebel group of 'Dyad C', however, only became part of a political power-sharing arrangement. One can see that it had to wait longer to see the implementation of this power-sharing to happen. Again, this stylized example partly reflects actual events in a post-conflict situation. After the previously mentioned peace agreement in the Democratic Republic of Congo, the RCD took over substantially more cabinet positions and leadership positions in the national army than either the MLC or RCD-ML did. Our data collection provides a detailed mapping of the differences in this and other post-conflict situations and therefore allows analysis of how differences between rebel signatories to the same peace deal affect the post-conflict situation overall.

\section{Data sources}

We collected data on the promises and practices of power-sharing for each governmentrebel dyad that had signed a peace agreement between 1989 and 2006. Regarding the 
promises of power-sharing, we used the official documents of the peace agreements for our coding. These documents were downloaded from the UCDP Conflict Encyclopedia (Uppsala Conflict Data Program, 2013). Any additional official documents were obtained with web searches. If some of the missing documents could not be retrieved, we relied on secondary literature to capture the content of the respective peace agreements.

The primary source of information for the practices of power-sharing was the country reports of the Economist Intelligence Unit (EIU). These reports are published for every country on at least a quarterly basis, and provide an up-to-date overview of national level political events. When the information on possible events given by EIU reports did not permit a proper coding, we conducted follow-up searches using the Africa Research Bulletin, Africa Yearbook, CIA World Leaders Database, Integrated Regional Information Networks, LexisNexis, Statesman's Yearbook and the PARLINE database of the InterParliamentary Union. The initial coding of the PSED events was conducted by research assistants and then checked and further processed by the principal investigators to ensure the reliability and quality of the data obtained.

\section{Data limitations}

Our detailed data collection on the promises and practices of power-sharing made between government and rebels allows in-depth analyses of the post-conflict interactions of these actors. Naturally, however, this exclusive focus precludes the use of the PSED for alternative research objectives.

To begin with, the PSED does not include data on power-sharing that has evolved out of situations not captured by the UCDP definition of civil conflict. Examples include the electoral violence and subsequent power-sharing arrangements in Kenya and Zimbabwe in 2008. The main reason for excluding these instances of electoral conflict and power-sharing is our understanding of civil conflicts and post-conflict situations as unique contexts. The existence of non-state, militarily organized groups and the political, social and economic legacies of protracted armed conflict simply require different power-sharing arrangements than powersharing arrangements resulting from disputed elections. At the same time, the use of therelatively low-UCDP threshold for civil conflicts of 25 battle-related deaths guarantees that we still capture the wide variety of low-scale armed conflicts present in the post-Cold War world.

Second, we only capture the promises and practices of power-sharing that occur between the government and those rebel groups that have signed a peace agreement. This means that we disregard the promises and practices of power-sharing between the government and societal groups such as, for example, ethnic or religious groups. The main rationale motivating this restriction is that the credible commitment theory focuses on the immediate conflict actors and their commitment to the peace agreement they have signed. As already explained above, the causal mechanisms of power-sharing between government and societal groups can be very different. ${ }^{11}$ Also, we do not collect data on power-sharing deals between non-state actors in areas of a country 'liberated' from the central government. While such arrangements are undoubtedly an important element of contemporary post-conflict situations, power-sharing between non-state actors is out of the conceptual scope of the present data collection and its focus on power-sharing arrangements at the national level. Moreover, collecting such data constitutes a formidable challenge owing to the inaccessibility of these areas. 
Table 2. Descriptive statistics on post conflict periods

\begin{tabular}{llllll}
\hline & World & Europe & Asia & Africa & Americas \\
\hline Frequency & 111 & 9 & 31 & 66 & 5 \\
Civil conflict recurrence & 55 & 0 & 22 & 33 & 0 \\
Multiple signatories & 45 & 0 & 17 & 28 & 0 \\
\hline
\end{tabular}

Finally, our dataset does not contain information on informal means of power-sharing between government and rebels in post-conflict countries. This omission can be explained by the data sources used for coding. While the EIU reports capture the central patterns and dynamics of power-sharing between government and rebels in post-conflict countries, their reporting is limited when it comes to informal means of power-sharing between former conflict actors. For example, we were unable to find information on verbal agreements between government and rebel representatives defining the size and powers of particular cabinet portfolios or the actual procedures for rebel-military integration. The PSED is therefore not suited to being a data source for analyses focusing on these aspects of power-sharing in post-conflict countries.

\section{The data}

Table 2 shows descriptive statistics for a set of variables that characterize post-conflict periods, both at the global level and disaggregated by world regions. Overall, there are 111 distinct post-conflict government-rebel dyads. ${ }^{12}$ Forty-five of these government-rebel dyads were part of a peace agreement that encompassed more than one dyad. Fifty-five out of the 111 government-rebel dyads experienced a civil conflict recurrence within five years. All dyads related to multiple signatories and those that experienced a return to violence cluster exclusively in Asia and Africa.

\section{Dimensions of power-sharing}

Table 3 reports the variable descriptions of the promises of power-sharing, as well as the frequency of their occurrence. As already mentioned above, these variables are time-invariant as the promises of power-sharing for each government-rebel dyad are based on the initial peace agreement between this dyad and are assumed to not change over time. The frequency and percentage columns in Table 3 are consequently based on a total $N$ of 111 (i.e. the overall number of government-rebel dyads in the PSED). In Table 4 we report the variable descriptions of the practices of power-sharing and the frequency of their occurrence. Overall, we record 548 distinct power-sharing events in our observation period.

The category 'promises of political power-sharing' focuses on the executive and legislative realm of national power. We recorded when governments promised the rebel group signatory to the peace agreement seats in the national government cabinet and when the government promised particular senior and/or non-senior cabinet positions. ${ }^{13}$ We also recorded when the rebel group signatory was promised guaranteed seats in the national parliament. Table 3 reveals that, in almost half of all government-rebel dyads in the PSED, the rebels were promised a seat in the cabinet (45\%). More specific promises about particular senior $(12 \%)$ and/ or non-senior $(26 \%)$ seats were significantly less frequent. Likewise, rebels were only 
Table 3. Descriptive statistics for promises of power sharing

\begin{tabular}{llr}
\hline Variable description & Frequency & Percentage \\
\hline The rebel group signatory is promised ... & & \\
$\ldots$ cabinet position(s) & 50 & 45.05 \\
$\ldots$ senior cabinet position(s) & 13 & 11.71 \\
$\ldots$ non senior cabinet position(s) & 29 & 26.13 \\
$\ldots$ guaranteed seats in the national parliament & 13 & 11.71 \\
$\ldots$ integration into the national army command & 10 & 9.01 \\
$\ldots$ integration of rebel forces into the national army, police & 46 & 41.44 \\
and/or paramilitary forces & & \\
$\ldots$ seat(s) in economic institutions & 11 & 9.91 \\
$\ldots$ a law or government that will introduce devolution & 26 & 23.42 \\
$\ldots$ a law or government that will introduce autonomy & 11 & 9.91 \\
\hline
\end{tabular}

promised guaranteed seats in the national parliament in roughly $12 \%$ of all governmentrebel dyads in our data collection. Turning to the actual practices of power-sharing, one can see that political power-sharing is the most frequent form of power-sharing in our observation (see Table 4). Almost $45 \%$ of all observed power-sharing events were events in which rebel representatives took over senior or non-senior cabinet positions or were given guaranteed seats in the national parliament. Importantly, however, rebels were primarily given political power in the form of non-senior cabinet positions. Events in which rebels moved into positions of political power happened about twice as often as events in which rebels left these positions, as we did not code rebel departures that were due to the recurrence of armed combat between government and rebels.

The case of the 2006 Comprehensive Peace Agreement in Nepal serves as an illustrative example for the detailed information on political power-sharing included in the PSED. As promised herein, the rebel Communist Party of Nepal (CPN-M) took over cabinet seats in the interim government in Kathmandu. Over the course of the post-conflict period, the rebels occupied a number of different cabinet positions and our data provides us with details on the particular posts. With this information, one can see that these cabinet positions had a high strategic importance for the rebels. The CPN-M representatives took over the Ministry of Local Development and the Ministry of Agriculture and Cooperatives. Both ministries are connected with the main conflict issues: the importance of local land distribution and horizontal inequalities between regions (Murshed and Gates, 2005). Furthermore, the rebels took over the Information and Communication Ministry - which was crucial for the upcoming elections as it guaranteed the rebels direct access to the state-owned radio and television stations, as well as to two national newspapers.

The promise of military power-sharing category captures if a rebel signatory to a peace agreement was promised that high-ranking rebel officers would be integrated into the national army command. Furthermore, we coded whether the rebel signatory was promised the integration of its fighters into the national army, police or paramilitary forces. Regarding the former, our data reveals that high-level military integration was only promised in $9 \%$ of all government-rebel dyads in our dataset. Rebel-military integration, however, was promised to 46 of the 111 rebel groups under analysis $(41 \%)$. This is the second most frequent promise of power-sharing (see Table 3). Examining the actual practices of 
Table 4. Descriptive statistics for practices of power sharing

\begin{tabular}{lrr}
\hline Variable description & Frequency & Percentage \\
\hline Rebel representative(s) ... & & \\
$\ldots$ take over a senior cabinet position & 71 & 12.96 \\
$\ldots$ leave a senior cabinet position & 30 & 5.47 \\
$\ldots$ take over a non senior cabinet position & 162 & 29.56 \\
$\ldots$ leaves a non senior cabinet position & 11 & 17.34 \\
$\ldots$ take over guaranteed seats in the national parliament & 8 & 2.01 \\
$\ldots$ leave guaranteed seats in the national assembly & 23 & 1.46 \\
$\ldots$ are integrated into the national army command & 2 & 4.20 \\
$\ldots$ leave the national army command & 113 & 0.36 \\
$\ldots$ are integrated into the national army, police and/or & & 20.62 \\
paramilitary forces & 12 & 2.19 \\
$\ldots$ take over seats in economic institutions & 4 & 0.73 \\
$\ldots$ lose seats in economic institutions & & 1.64 \\
A law or government decree ... & 9 & 0 \\
$\ldots$ is passed that introduces devolution & 0 & 1.46 \\
$\ldots$ is abolished that introduced devolution & 8 & 0 \\
$\ldots$ is passed that introduces autonomy & 0 & 100 \\
$\ldots$ is abolished that introduced autonomy & $\mathbf{5 4 8}$ & \\
Total & & \\
\hline
\end{tabular}

military power-sharing, one can see that there were only 23 occurrences of rebel-military command integration and only 113 occurrences of rank and file military integration. Overall, military power-sharing events only comprised $25 \%$ of all recorded events in our data collection (see Table 4). Rebel-military command integration as well as rank and file integration took place primarily in conflicts where the rebel forces were militarily strong in relation to government forces, as in the case of the Angolan UNITA or the rebel groups in the Democratic Republic of Congo.

Promises of economic power-sharing between government and rebels in a peace agreement were operationalized as the announced inclusion of rebel representatives in stateowned companies and in commissions regulating certain natural resources or sectors of the country's economy. Table 3 reports that such promises were only given in 11 of the 111 government-rebel dyads. Our event data then captures the time when economic powersharing began and when it ended. We found such economic power-sharing only to have existed in seven government-rebel dyads in six countries (see Table 4). Arrangements between the Liberian government and the rebel groups Liberians United for Reconciliation and Democracy (LURD) and Movement for Democracy in Liberia (MODEL), and the Burundian government and the rebel movement Forces for the Defense of Democracy (CNDD-FDD), make up 12 of the 18 events in the PSED. In light of this, economic powersharing - per our understanding of it — is a rather infrequent event.

Our data collection distinguishes between two territorial power-sharing dimensions: devolution and autonomy. ${ }^{14}$ Devolution is the granting of political, financial or administrative powers from the central government to authorities at the subnational level. Autonomy covers when an entity in an area of a country has a substantial degree of political autonomy or freedom from the central government of the state. There are $26(23 \%)$ promises of territorial devolution and $11(10 \%)$ promises of autonomy in our data (see Table 3). Implementation of territorial power-sharing was only coded if a new territorial structure was adopted by law. 
This coding rule has the advantage of including only cases wherein a credible commitment was made regarding a new territorial structure. Table 4 reports that there were nine cases of implemented devolution agreements and eight instances of implemented autonomy agreements. These implemented territorial power-sharing agreements were located in Angola, Bangladesh, Bosnia-Herzegovina, Comoros, Croatia, Georgia, Indonesia, Macedonia, Mali, Moldova, Papua-New Guinea, Philippines, Serbia, Sudan and the UK. Our data also indicates that, once a law had been adopted, territorial power-sharing would not be abolished during the post-conflict phase.

Furthermore, the PSED includes information on promises and practices that are not related directly to power-sharing but nevertheless important for analyzing it. We recorded when an electoral system with proportional representation elements was promised in the peace agreement and eventually introduced or abolished by the national parliament, the promise and eventual date of all national-level elections and referenda, and the promise and eventual introduction of new constitutions and/or important constitutional amendments. Finally, we recorded when government and rebels left important issues in the peace agreements unresolved and when they agreed on a post-conflict settlement modifying or extending the terms of the original peace accord. Table 5 shows the frequency distribution of these variables.

\section{Regional and temporal patterns of power-sharing}

Lastly, we discuss the regional and temporal distribution of the practices of power-sharing. Figure 1 reports the respective percentages of rebel events falling into political, military, economic or territorial power-sharing dimensions across world regions. One can see that the vast majority of power-sharing occurred in Africa. Seventy percent of all political, $80 \%$ of all military and $90 \%$ of the economic power-sharing events took place in African post-conflict periods. Only territorial power-sharing $(30 \%)$ was a relatively infrequent occurrence in this world region. Even when one considers that more than half of all post-conflict periods were located in Africa, these numbers still signify that power-sharing in this world region represented a disproportionally high share of all global events. In contrast, power-sharing in Europe was primarily dominated by territorial arrangements. Almost $50 \%$ of all territorial power-sharing events occurred in this world region. Power-sharing in Asian post-conflict

Table 5. Descriptive statistics for post conflict promises and practices unrelated to power sharing

\begin{tabular}{lll}
\hline Variable description & $\begin{array}{l}\text { Promises } \\
\text { frequency }\end{array}$ & $\begin{array}{l}\text { Practices } \\
\text { frequency }\end{array}$ \\
\hline A law or government decree ... & & 19 \\
$\ldots$ is promised/passed that introduces proportional representation & 8 & 2 \\
$\ldots$ is abolished that introduced proportional representation & 56 & 130 \\
National elections are promised/taking place & 12 & 26 \\
A referendum is promised/taking place & 32 & 36 \\
A new constitution is promised/enacted & 73 & 40 \\
Government-rebel dyad leaves important issues unresolved/negotiates a & & \\
subsequent agreement & & \\
\hline
\end{tabular}




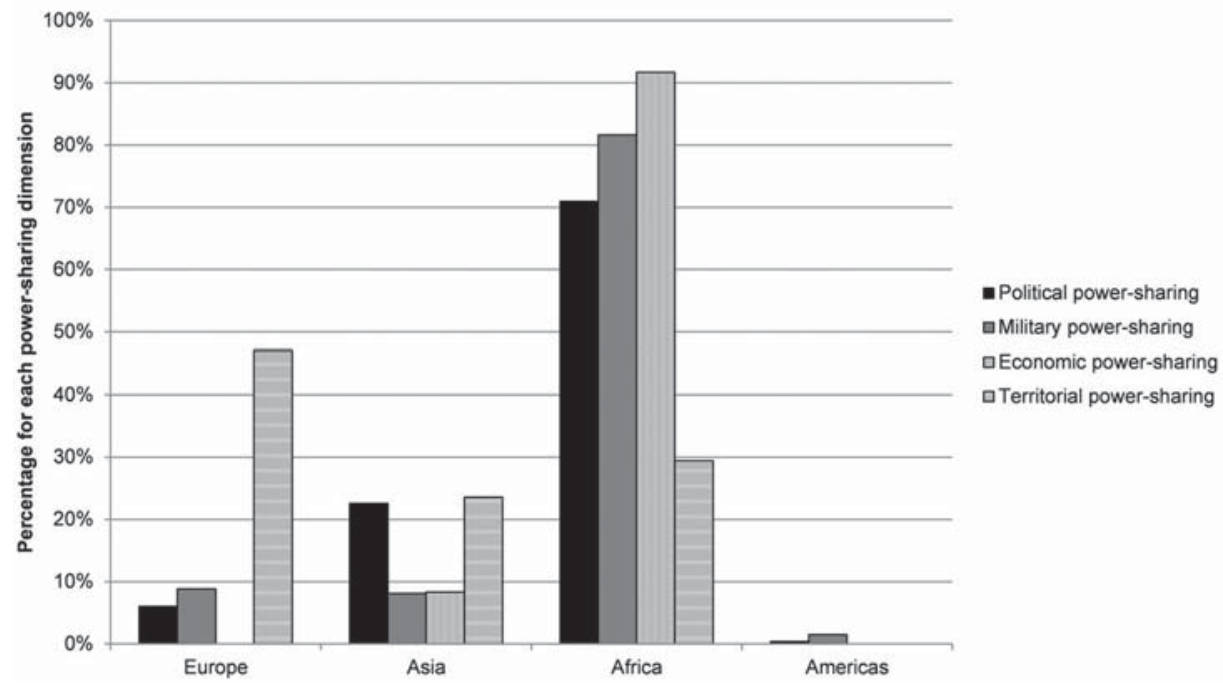

Figure I. Respective percentages of power sharing events in the political, military, economic and territorial dimensions across world regions.

Note: Only events marking the beginning of power-sharing arrangements are included.

countries was characterized by political and territorial arrangements (both slightly above $20 \%$ ), whereas military and economic power-sharing events were both below $10 \%$ in this world region. Finally, one rarely sees power-sharing events for the post-conflict periods of the Americas. The regional distribution of power-sharing shows that this conflict resolution tool was primarily used in the aftermath of civil conflicts occurring on the African continent.

Turning to the temporal distribution of power-sharing events, Figure 2 shows the respective percentages of events falling into political, military, economic or territorial powersharing dimensions for each of the five post-conflict years. It is remarkable that the vast majority of all power-sharing events cluster in the first year after a peace agreement was signed. Up to $60 \%$ of power-sharing events in the political, economic and territorial dimensions occurred in the first year of the post-conflict period under analysis. Military powersharing occurred less frequently in the first year, but still accounts for about $45 \%$ of all such events.

While we still see about $20 \%$ of all political power-sharing events in the second postconflict year, these were relatively infrequent in the remainder of the post-conflict period. In contrast, military power-sharing was slightly more evenly distributed over time. In the second year, almost $30 \%$ of these events occurred, with about $10 \%$ taking place in the third and fourth years respectively. As economic and territorial power-sharing events occur relatively infrequently in the PSED, an interpretation of their temporal distribution is liable to be less meaningful. Nonetheless, it is worth pointing out that more than $30 \%$ of all economic power-sharing events occurred in the third post-conflict year and that territorial powersharing events were the most frequent events to occur in the fifth post-conflict year. Given the overall dominance of political and military power-sharing, it appears that power-sharing is primarily a phenomenon of the first two years of the post-conflict period. 


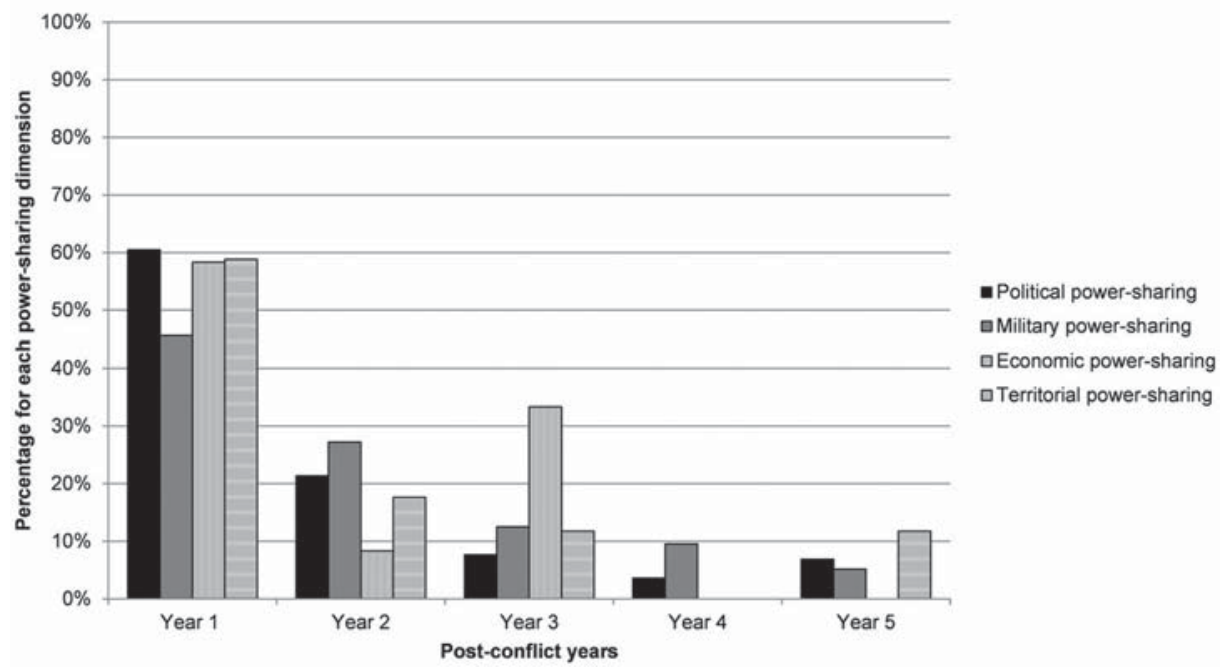

Figure 2. Respective percentages of power sharing events in the political, military, economic and territorial dimensions across time.

Note: Only events marking the beginning of power-sharing arrangements are included.

However, the PSED shows that the implementation of peace agreements is not straightforward. There can be substantial temporal variation in the establishment of power-sharing practices over time. The PSED data on the implementation of the 2005 Pretoria Agreement between the Ivorian government and the rebel New Forces illustrates this perfectly. In the Pretoria Agreement, the Ivorian government and the New Forces agreed upon, among other things, a government of national unity and rebel-military integration. Figure 3 shows the temporal sequence of these power-sharing events in the five years following the signature of the settlement. It took both parties eight months until a government of national unity was actually established, with representatives of the New Forces not occupying any senior cabinet positions in it. The peace process was repeatedly interrupted by disputes over the (in)adequate representation of rebels in the government and the military power-sharing arrangements established. In the end, it took two years until rebel leader Guillaume Soro officially became Prime Minister by the decree of President Gbagbo. At this point, rebel officers took over positions in the national army command and rebel fighters were integrated into army units.

\section{Using the data}

The three main features of the PSED are its consistent focus on the government-rebel dyad as the central level of analysis, the exact temporal mapping of the practices of power-sharing and accompanying detailed descriptions of each of these power-sharing practices. These features allow a more focused and disaggregated analysis of power-sharing in post-conflict countries than is possible with already existing data collections on this phenomenon. In this section, we will illustrate the utility of these improvements with a statistical analysis of the effects of the promises of power-sharing and their actual implementation in the post-conflict 


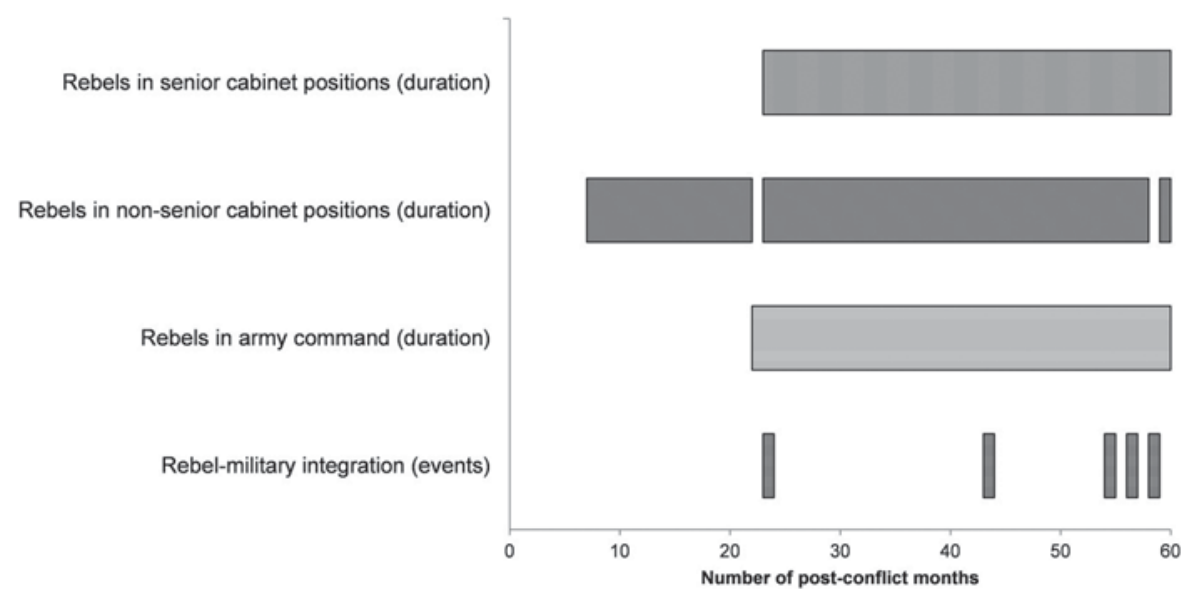

Figure 3. Post conflict events in Côte d'lvoire, 2005-2010.

period on the probability that civil conflict recurs. The results of our statistical analysis cast new light on past studies on power-sharing in post-conflict countries and point to new directions for future research.

\section{Promises of power-sharing and their eventual implementation}

One of the few systematic studies making a conceptual and empirical difference between the effect of the promises of power-sharing and the implementation of these promises on civil conflict recurrence is Jarstad and Nilsson's (2008) analysis on power-sharing pacts. Based on bargaining theory, they argue that the giving and implementation of promises of powersharing serves as a costly signal building much needed trust between the former conflict parties. They find empirical evidence supportive of their hypothesized relationship with a statistical analysis employing data on political, military and territorial power-sharing provisions and whether these provisions have been implemented at the end of a five-year period. In particular, they find that implementing costly military and territorial provisions increases the likelihood of peace, while the less costly implementation of political power-sharing pacts does not increase the prospects of peace.

In the following empirical application of the PSED, we follow Jarstad and Nilsson's (2008) theoretical framework. We hypothesize that promises of power-sharing and - even more so - their eventual implementation serve as costly signals to each conflict party that the intention to resolve the civil conflict is a credible commitment. We also follow their assumption that different types of power-sharing arrangements might be more suitable to achieve this objective than others. We think, however, that Jarstad and Nilsson's research design is insufficient to substantiate their central hypothesis. To begin with, their analysis uses the aggregate peace agreement level as a unit of analysis. This conceptual focus on peace agreements at a whole is insufficient to test the very clearly actor-focused propositions of bargaining theory. Second, Jarstad and Nilsson's data collection merely looks at the implementation status of these power-sharing provisions at the end of a five-year period, thereby disregarding the temporal sequence of power-sharing implementation. With the PSED, we are able to 
address these conceptual and empirical gaps in Jarstad and Nilsson's study. Our new data collection allows an empirical test of the actor-specific and time-sensitive propositions of the bargaining situation between government and rebels in post-conflict situations.

\section{Operationalization}

Our empirical application of the PSED uses the government-rebel dyad in a given postconflict month as unit of analysis. The dependent variable is a binary variable taking the value of 1 if armed violence between the government and the rebel group recurs and causes 25 or more battle-related deaths.

Mirroring the empirical analysis of Jarstad and Nilsson (2008), we use two sets of explanatory variables. First, we have four binary variables capturing whether a rebel group has been given promises of power-sharing in the political, military, economic and territorial dimension of power. For each dimension, the binary variable takes the value of 1 when the government has promised the rebel group that at least one particular power-sharing institution in the respective dimension will be established. These variables are time-invariant. Second, we have four binary variables capturing whether the initial promises of power-sharing have been kept. For each dimension of power, the binary variable takes the value of 1 when power-sharing in a particular dimension of power has been promised and the first practice of power-sharing in this dimension is established. It remains 1 as long as this implemented power-sharing institution is active.

In terms of control variables, we include those variables most commonly used in past research on post-conflict power-sharing and civil conflict recurrence while keeping our models as parsimonious as possible (e.g. Hartzell and Hoddie, 2003; Jarstad and Nilsson, 2008; Mattes and Savun, 2009). First, we include three variables controlling for the characteristics of the civil conflict resolved by the peace agreement. We include a binary variable assuming the value of 1 when a civil conflict has been fought over a particular territory within a country and the value of 0 when the civil conflict has been fought over control of national government. Territorial conflicts are assumed to be less likely to experience renewed conflict as such localized conflicts are easier to pacify with power-sharing concessions than conflicts fought over control of the entire state government. We also control for the length of the civil conflict measured from the day the civil conflict between the government of a state and a rebel group reached more than 25 battle-related deaths in a calendar year. Long-lasting conflicts might result in substantial war weariness, decreasing the probability of a civil conflict recurrence. Next, we include a binary variable taking the value of 1 when the civil conflict dyad between government forces and the rebel group includes at least one calendar year with more than 1000 battle-related deaths. Here, we expect that more intense conflicts harden the frontlines between the conflict parties, resulting in more protracted post-conflict situations. The data for these variables has been taken from the UCDP Dyadic Dataset (Harbom et al., 2008).

Turning to the configuration of the post-conflict setting under analysis, we first control for the presence of a United Nations peacekeeping mission. We expect that the presence of UN peacekeepers will function as third-party guarantor, thereby reducing the probability of renewed civil conflict. We include a binary variable taking the value of 1 when there is a United Nations Peacekeeping Operation in the post-conflict country under analysis (Hegre et al., 2011). ${ }^{15}$ Finally, we utilize the PSED itself to construct a binary variable taking the value of 1 when there is more than one government-rebel dyad in the post-conflict period to 
control for peace agreements with multiple rebel group signatories and 0 otherwise. We expect multiparty peace agreements to be rather unstable and therefore more prone to conflict relapses.

Admittedly, there are a number of additional factors that could have been used as additional control variables such as, for example, the economic development of the country under analysis, its regime type, the presence of natural resources or rebel group characteristics. For the present purpose of illustrating the benefit of the PSED, however, we opted for a parsimonious model. Future analyses of post-conflict power-sharing using the PSED will make use of more refined models.

\section{Empirical findings}

For our statistical analysis, we structure our monthly data on the promises and implementation of post-conflict power-sharing and civil conflict recurrence into a binary time-series cross section data format (Beck et al., 1998). We consequently use a logistic regression model with robust standard errors clustered on the government-rebel dyad to account for heteroskedasticity and serial correlation. ${ }^{16} \mathrm{We}$ also include the number of post-conflict months and its squared and cubed terms to approximate the hazard of peace failing since the signature of the peace agreement (Carter and Signorino, 2010).

Following Jarstad and Nilsson (2008), we estimate three models with the same combinations of explanatory variables. The statistical results are reported in Table 6. To begin with, we find that the variables accounting for time dependency are statistically insignificant in all estimated models. Regarding the control variables, only two of these variables have statistically significant coefficients. We find that more intense civil conflicts and the presence of multiple rebel signatories to the peace agreement increase the likelihood of renewed civil conflict. While being statistically insignificant, the signs of the coefficients of the remaining variables nevertheless behave as expected. Given the restricted space available for this first empirical application of the PSED, we refrain from further discussion of these control variables. We hope to shed further light on the impact of these and other context conditions on civil conflict recurrence in future analyses using the PSED.

Turning to explanatory variables, we only estimate the effect of the promises of powersharing on civil conflict recurrence in model 1. As Jarstad and Nilsson, we find the coefficient for the promises of political power-sharing to increase the likelihood of renewed civil conflict. As in their regression, however, the coefficient is statistically insignificant. Our estimate for promises of territorial power-sharing decreases this risk and is statistically significant. In contrast to Jarstad and Nilsson's study, however, our analysis returns statistically significant effects for promises of military and economic power-sharing. Both promises of power-sharing reduce the likelihood of civil conflict recurrence. Using the PSED, our results therefore provide additional empirical support for Jarstad and Nilsson's (2008) claim that power-sharing promises that entail substantial costs for both conflict parties reduce the likelihood of renewed armed conflict.

In model 2, we replace the promises of power-sharing with our indicators measuring the existence of implemented promises of power-sharing. Here, our results differ substantially from Jarstad and Nilsson's results. While they find implemented promises of military and territorial power-sharing to be statistically significant predictors of a reduced likelihood of renewed conflict, we only find the implemented promises of military power-sharing to achieve this objective. The variable measuring implemented promises of territorial power- 
Table 6. Promises and implementation of power sharing and the recurrence of civil conflicts

\begin{tabular}{|c|c|c|c|}
\hline & Model I & Model 2 & Model 3 \\
\hline Promise of political power sharing & $\begin{array}{c}0.302 \\
(0.393)\end{array}$ & & $\begin{array}{l}0.933 * * \\
(0.429)\end{array}$ \\
\hline Promise of military power sharing & $\begin{array}{l}0.858 * * \\
(0.414)\end{array}$ & & $\begin{array}{l}0.939 * * \\
(0.427)\end{array}$ \\
\hline Promise of economic power sharing & $\begin{array}{c}2.124 * \\
(1.120)\end{array}$ & & $\begin{array}{l}\mid 4.627^{* * * *} \\
(0.864)\end{array}$ \\
\hline Promise of territorial power sharing & $\begin{array}{l}1.190 * * \\
(0.568)\end{array}$ & & $\begin{array}{c}1.029^{*} \\
(0.552)\end{array}$ \\
\hline Implemented promise of political power sharing & & $\begin{array}{l}0.412 \\
(0.336)\end{array}$ & $\begin{array}{l}1.267 * * * \\
(0.330)\end{array}$ \\
\hline Implemented promise of military power sharing & & $\begin{array}{c}2.063^{*} \\
(1.06 \mathrm{I})\end{array}$ & $\begin{array}{c}0.512 \\
(0.989)\end{array}$ \\
\hline Implemented promise of economic power sharing & & $\begin{array}{c}0.784 \\
(1.231)\end{array}$ & $\begin{array}{l}\text { I } 4.206 * * * \\
(1.460)\end{array}$ \\
\hline Implemented promise of territorial power sharing & & (.) & (.) \\
\hline Conflict incompatibility & $\begin{array}{c}0.525 \\
(0.642)\end{array}$ & $\begin{array}{c}0.650 \\
(0.537)\end{array}$ & $\begin{array}{c}0.308 \\
(0.594)\end{array}$ \\
\hline Conflict duration & $\begin{array}{c}0.000 \\
(0.000)\end{array}$ & $\begin{array}{c}0.000 \\
(0.000)\end{array}$ & $\begin{array}{c}0.000 \\
(0.000)\end{array}$ \\
\hline Conflict intensity & $\begin{array}{l}1.137 * * * \\
(0.330)\end{array}$ & $\begin{array}{l}0.945 * * * \\
(0.330)\end{array}$ & $\begin{array}{l}1.189 * * * \\
(0.342)\end{array}$ \\
\hline UN peacekeeping & $\begin{array}{c}0.102 \\
(0.370)\end{array}$ & $\begin{array}{c}0.364 \\
(0.361)\end{array}$ & $\begin{array}{c}0.276 \\
(0.415)\end{array}$ \\
\hline Multiple rebel signatories to the peace agreement & $\begin{array}{c}0.716^{*} \\
(0.377)\end{array}$ & $\begin{array}{l}0.983^{* * * *} \\
(0.348)\end{array}$ & $\begin{array}{c}0.725^{*} \\
(0.390)\end{array}$ \\
\hline Number of post conflict months & $\begin{array}{c}0.050 \\
(0.072)\end{array}$ & $\begin{array}{c}0.034 \\
(0.074)\end{array}$ & $\begin{array}{c}0.011 \\
(0.066)\end{array}$ \\
\hline Post conflict months polynomials & Omitted & Omitted & Omitted \\
\hline Constant & Omitted & Omitted & Omitted \\
\hline Observations & 3821 & 3236 & 3236 \\
\hline Log likelihood & 213.496 & 224.265 & 206.157 \\
\hline
\end{tabular}

Robust standard errors clustered on government rebel dyads in parentheses.

$* p<0.10, * * p<0.05, * * * p<0.01$.

sharing perfectly predicts the outcome of no civil conflict recurrence. This result might indicate that territorial power-sharing is actually only implemented when the risk of renewed civil conflict has already vanished. In model 2 , the actor-centric PSED data therefore reveals that costly signals given by the implementation of power-sharing deals in the military realm are the sole predictor of a reduced likelihood of civil conflicts.

In our final model we assess the impact of power-sharing implementation on civil conflict recurrence while controlling for the promises of power-sharing given at the outset of the postconflict period. Regarding the promises of power-sharing, model 3 features no substantial differences to the previous model. We only find that the coefficient capturing the promises of political power-sharing is now statistically significant. This supports Jarstad and Nilsson's (2008) assertion that promises of political power-sharing do not constitute a costly signal. As a matter of fact, it even appears that such promises might exacerbate the conflict between 
government and rebels. This might be due to the government being uneasy with such political concessions or to the rebels now expecting even more concessions. As in model 2, we find that the implementation of territorial power-sharing perfectly predicts the outcome of a postconflict period. More interestingly, we find that - once we control for the promises of powersharing - the implementation of military power-sharing is not relevant anymore. The coefficient still points in the hypothesized direction, but the coefficient is now statistically insignificant. Instead, we find implemented promises of political and economic power-sharing to exert a statistically significant negative effect on the risk of renewed conflict. This an important deviation from Jarstad and Nilsson's (2008) findings. First, it appears that the promises of power-sharing and their subsequent implementation follow different bargaining logics. Moreover, it appears that the impact of power-sharing implementation on civil conflict recurrence partly depends on the nature of the initial promises given to the rebel group.

Taken together, this first preliminary analysis using our unique PSED already provides us with important new insights into post-conflict power-sharing. The different impact of promises of power-sharing and their eventual implementation on the risk of civil conflict recurrence indicate different underlying bargaining logics. Apparently, mere promise seems to be sufficient to keep the peace. When it comes to the actual implementation of these promises, however, political and economic posts are more important than military or territorial concessions. The different findings regarding our actor-centric measures of political, military, economic and territorial promises and their implementation also imply that political and economic posts are more important than keeping true to the initial promises. Against this background, future analyses of post-conflict power-sharing need to pay more attention to the actual bargaining logic driving government and rebels' behavior and possible interactive effects between promises of power-sharing and their implementation.

\section{Conclusion}

This article introduced the Power-Sharing Event Dataset, which offers researchers unique and innovative data on the promises and practices of power-sharing between government and rebels in 41 post-conflict countries. The central contributions of this new data collection are an explicit focus on government-rebel dyads in post-conflict situations, information on power-sharing institutions in an event data format, and the detailed event descriptions provided for each type of these power-sharing institutions. With this data, it is now possible to move beyond the analysis of the mere provisions for power-sharing stipulated in peace agreements and investigate instead actual power-sharing events occurring during the five years after the end of civil conflict. Moreover, our data collection can be easily combined with already existing datasets on political violence, institutions and actors, which further opens up the analysis of the characteristics and dynamics of post-conflict situations.

Our preliminary analysis of the effect of promises of power-sharing and their implementation on civil conflict recurrence demonstrates the utility of the PSED in gaining new insights on post-conflict situations. Admittedly, this analysis only touched the surface of understanding the dynamics of government-rebel interactions in the aftermath of a peace agreement. We have demonstrated, however, that in-depth analyses of the promises and practices of power-sharing arrangements between governments and rebels are essential to better understand if and when civil conflict recurs. As researchers and practitioners alike are increasingly focusing on these determinants of peace in post-conflict countries, we hope that the PSED will contribute to a better understanding of these situations. 


\section{Acknowledgments}

We are grateful to Miriam Bach, John Martin Preuss, Daniela Späth, Katrin Wilkniss, Ingo Henneberg, Friedrich Plank, Katharina Newberry and Barbara Walter for their valuable research assistance. We would also like to thank Andreas Mehler, Caroline Hartzell, Alexander De Juan and Jan Pierskalla for their advice, comments and suggestions on earlier drafts of the manuscript. Last but not least, we would like to thank Glenn Palmer and three anonymous reviewers for their helpful comments.

\section{Funding}

This data collection is part of the research project 'Power sharing in post conflict situations: On the institutional prerequisites for lasting peace' funded by the German Research Foundation.

\section{Notes}

1. The dataset, codebook and replication data for this data feature are available on the website of the GIGA German Institute for Global and Area Studies (http://www.giga hamburg.de/en/ project/PSED).

2. Our definition of 'civil conflict' is taken from the definitions and operationalizations of the Uppsala Conflict Data Program. We understand a civil conflict as any armed conflict between the government of a state and internal oppositions groups that concerns government or territory or both "where the use of armed force between two parties results in at least 25 battle related deaths' (Gleditsch et al., 2002: 618f). We elaborate on the use of UCDP definitions in the third section of this data feature.

3. Another dataset collecting information on the implementation of power sharing agreements is the Peace Accord Matrix (Joshi and Darby, 2013), which includes 51 provisions and their implemen tation status on a yearly basis in 35 negotiated settlements (1989 2007). This database, however, is primarily of a qualitative nature.

4. We consulted UCDP data (Kreutz, 2010; Sundberg and Melander, 2013; Uppsala Conflict Data Program, 2013) and the Armed Conflict and Location Event Dataset (Raleigh et al., 2010) to determine whether armed conflict between the signatories to a peace agreement recurred earlier.

5. Examples include the Social Conflict in Africa Database (Salehyan et al., 2012) and the Non State Actor Dataset (Cunningham et al., 2013).

6. Scholars have the option to just analyze a subset of high intensity civil conflicts using the conflict intensity variable present in each UCDP dataset. With this variable, one can distinguish those con flict periods that have never crossed the 1000 battle related deaths threshold during the course of the entire civil conflict from those conflicts that have crossed this threshold.

7. While we exclude these arrangements and institutions from our definition of power sharing, we nevertheless collect data on some of their promises and practices. As explained in the following data presentation, the PSED also provides data on proportional representation, national elections and referenda and new constitutions.

8. We would like to thank one of our anonymous reviewers for emphasizing the importance of clearly differentiating between the promises and practices of power sharing.

9. We also provide a version of the PSED using the peace agreement in the post conflict period as the unit of analysis. This dataset aggregates the government rebel dyads of each peace agreement and captures power sharing between the government of a state and all rebel signatories to the peace agreement under analysis. This PSED version can also be found on the GIGA German Institute for Global and Area Studies website (http://www.giga hamburg.de/en/project/PSED).

10. As we will explain in the subsequent section, the PSED also captures when a government rebel dyad negotiates a follow up agreement during the post conflict period. Very often, these post 
conflict agreements specify or modify arrangements that have been outlined in the initial peace agreement.

11. Nevertheless, the PSED collects data on some of these power sharing arrangements, such as, for example, the introduction of proportional representation (for details please see below). To account for power sharing arrangements on a constitutional level, the data collection can be also easily be merged with datasets on countries' constitutional design, such as, for example, the Institutions and Elections Project (Regan et al., 2009).

12. According to the UCDP Conflict Termination Dataset (Kreutz, 2010), 192 government rebel dyads ended without the conflict parties having signed a peace agreement or ceasefire agreement between 1989 and 2006. That is, the 111 government rebel dyads in PSED represent about a third of all government rebel dyads ending between 1989 and 2006.

13. The following cabinet positions and ministries were coded as being 'senior': President, Vice President, Prime Minister, Deputy Prime Minister, Foreign Affairs, Defense, Interior, Justice, Finance, Economy and Resources.

14. Territorial power sharing could not be completely captured with our actor centric focus, as it addresses geographically concentrated ethnic groups. However, if we had just coded those instances in which particular rebel groups were promised or gained control over a particular terri tory then the promise and practice of territorial power sharing in post conflict countries would have been underestimated. Therefore, we already coded territorial power sharing when it referred to the relations between the national government and a particular territorial entity represented by the rebel group signatory. In fact, rebel signatories eventually take over control of these territories anyway.

15. We thank Håvard Hegre, Lisa Hultman and Håvard Mokleiv Nygård for granting us access to their UN peacekeeping data. We extended their data collection up to 2011.

16. Beck et al. (1998: 1266) explain that binary time series cross section (BTSCS) data are identical to grouped duration data and that BTSCS models are derived 'from an underlying continuous time Cox proportional hazards model'. Moreover, they also state that a BTSCS model is 'easier to esti mate and does not suffer from some problems inherent in the continuous time model' (Beck et al., 1998: 1266). Against this background, we decided to use a BTSCS model for this first empirical application of the PSED.

\section{References}

Beck N, Katz JN and Tucker R (1998) Taking time seriously: Time series cross section analysis with a binary dependent variable. American Journal of Political Science 42(4): 12601288.

Binningsbø HM (2006) Power sharing and post conflict peace periods. Paper prepared for the 47th Annual Convention of the International Studies Association, San Diego, CA, 2225 March 2006.

Binningsbø HM (2013) Power sharing, peace and democracy: Any obvious relationships? International Area Studies Review 16(1): 89112.

Binningsbø HM and Rustad SA (2012) Sharing the wealth: A pathway to peace or a trail to nowhere? Conflict Management and Peace Science 29(5): 547566.

Cammett M and Malesky E (2012) Power sharing in postconflict societies: Implications for peace and governance. Journal of Conflict Resolution 56(6): 9821016.

Carter DB and Signorino CS (2010) Back to the future: Modeling time dependence in binary data. Political Analysis 18(3): 271292.

Cunningham DE, Gleditsch KS and Salehyan I (2013) Non state actors in civil wars. A new dataset. Conflict Management and Peace Science 30(5): 516531.

DeRouen K Jr, Ferguson MJ, Norton S, Park YH, Lea J and Streat Bartlett A (2010) Civil war peace agreement implementation and state capacity. Journal of Peace Research 47(3): 333346. 
Gates S and Strand H (2004) Modeling the duration of civil wars: Measurement and estimation issues. Paper presented at the Meeting of the Standing Group on International Relations, The Hague, 911 September 2004.

Glassmyer K and Sambanis N (2008) Rebel military integration and civil war termination. Journal of Peace Research 45(3): 365384.

Gleditsch NP, Wallensteen P, Eriksson M, Sollenberg M and Strand H (2002) Armed Conflict 1946 2011: A new dataset. Journal of Peace Research 39(5): 615637.

Harbom L, Melander E and Wallensteen P (2008) Dyadic dimensions of armed conflict, 19462007. Journal of Peace Research 45(5): 697710.

Hartzell CA and Hoddie M (2003) Institutionalizing peace: Power sharing and post civil war conflict management. American Journal of Political Science 47(2): 318332.

Hartzell CA and Hoddie M (2007) Crafting Peace: Power sharing Institutions and the Negotiated Settlement of Civil Wars. University Park, PA: Pennsylvania State University Press.

Hegre H, Hultman L and Nygård HM (2011) Simulating the effect of peacekeeping operations 2010 2035. In: Social Computing, Behavioral Cultural Modeling and Prediction. Lecture Notes in Computer Science, Vol. 6589. Berlin: Springer, pp. 325332.

Hoddie M and Hartzell CA (2003) Civil war settlements and the implementation of military power sharing arrangements. Journal of Peace Research 40(3): 303320.

Hoddie M and Hartzell CA (2005) Power sharing in peace settlements: Initiating the transition from civil war. In: Roeder PG and Rothchild D (eds) Sustainable Peace: Power and Democracy after Civil Wars. Ithaca, NY: Cornell University Press.

Jarstad AK and Nilsson D (2008) From words to deeds: The implementation of power sharing pacts in peace accords. Conflict Management and Peace Science 25(3): 206223.

Jarstad AK and Sisk TD (eds) (2008) From War to Democracy. Dilemmas of Peacebuilding. Cambridge: Cambridge University Press.

Joshi M and Darby J (2013) Introducing the Peace Accords Matrix (PAM): A database of comprehensive peace agreements and their implementation, 1989 2007. Peacebuilding 1(2): 256274.

Kreutz J (2010) How and when armed conflicts end: Introducing the UCDP Conflict Termination dataset. Journal of Peace Research 47(2): 243250.

Lake DA and Rothchild D (2005) Territorial decentralization and civil war settlements. In: Roeder PG and Rothchild D (eds) Sustainable Peace: Power and Democracy after Civil Wars. Ithaca, NY: Cornell University.

Lijphart A (1969) Consociational democracy. World Politics 15(1): 207225.

Mattes M and Savun B (2009) Fostering peace after civil war: Commitment problems and agreement design. International Studies Quarterly 53(3): 737759.

Mehler A (2009) Peace and power sharing in Africa: A not so obvious relationship. African Affairs 108(432): 453473.

Mukherjee B (2006) Why political power sharing agreements lead to enduring peaceful resolution of some civil wars, but not others? International Studies Quarterly 50(2): 479504.

Murshed SM and Gates S (2005) Spatial horizontal inequality and the Maoist insurgency in Nepal. Review of Development Economics 9(1): 121134.

Norris P (2008) Driving Democracy: Do Power sharing Institutions Work? Cambridge: Cambridge University Press.

Pearson F, Lounsberry MO, Walker S and Mann S (2006) Rethinking models of civil war settlement. International Interactions 32(2): 109128.

Raleigh C, Linke A, Hegre H and Karlsen J (2010) Introducing ACLED: An armed conflict location and event dataset. Journal of Peace Research 47(5): 651660

Regan PM, Frank RW and Clark DH (2009) New datasets on political institutions and elections, 1972 2005. Conflict Management and Peace Science 26(3): 286304. 
Roeder PG and Rothchild D (eds) (2005) Sustainable Peace: Power and Democracy after Civil Wars. Ithaca, NY: Cornell University Press.

Rothchild D and Roeder PG (2005) Power sharing as an impediment to peace and democracy. In: Roeder PG and Rothchild D (eds) Sustainable Peace: Power and Democracy after Civil Wars. Ithaca, NY: Cornell University Press.

Salehyan I, Hendrix CS, Hamner J, Case C, Linebarger C, Stull E and Williams J (2012) Social conflict in Africa: A new database. International Interactions 38(4): 503511.

Snyder JL and Jervis R (1999) Civil war and the security dilemma. In: Walter BF and Snyder JL (eds) Civil Wars, Insecurity and Intervention. New York, NY: Columbia University Press.

Sundberg R and Melander E (2013) Introducing the UCDP Georeferenced Event Dataset. Journal of Peace Research 50(4): 523532.

Tull DM and Mehler A (2005) The hidden costs of power sharing: Reproducing insurgent violence in Africa. African Affairs 104(416): 375398.

Uppsala Conflict Data Program (2013) UCDP Conflict Encyclopedia. Uppsala University. Available from: http://www.ucdp.uu.se/gpdatabase/search.php (accessed 31 March 2013).

Walter BF (1999) Designing transitions from civil war: Demobilization, democratization, and commitments to peace. International Security 24(1): 127155.

Walter BF (2002) Committing to Peace: The Successful Settlement of Civil Wars. Princeton, NJ: Princeton University Press. 